\title{
Implementation of the Role of Higher Education in the Vocational Sector in the Penta Helix Model
}

\author{
Darius Shyafary ${ }^{1}$, Heldina Pristanti ${ }^{2}$, Dwi Cahyadi ${ }^{3}$ \\ \{dwicahyadi@polnes.ac.id ${ }^{3}$ \} \\ Design Department, Politeknik Negeri Samarinda, 75136, Indonesia ${ }^{1,3}$ \\ Business Administration Department, Politeknik Negeri Samarinda, 75136, Indonesia ${ }^{2}$
}

\begin{abstract}
University with all its capabilities must synergize with industry and government, so as to be able to produce new innovations, and create development strategies that are guided by tertiary institutions to respond to development challenges in various fields. Development The application of the Penta Helix model in education, especially vocational education, has not been studied much. The vocational field, especially those related to the creative economy, which is a priority for vocational education in Indonesia, needs to be studied more deeply. Therefore, this research will study the Penta Helix model in the Product Design Department of Samarinda State Polytechnic as vocational education in the creative economy field. The purpose of this study is to analyze the extent to which the Penta Helix innovation model is applied in the Product Design Study Program. especially in synergy with industry, government, mass media, and society in the creative economy of product design. This research method is to use the snowball technique, this technique is a multilevel technique, based on the snowball analogy. The results of the study found that the Penta Helix concept, especially in the field of vocational education, can be applied through the empowerment of the three main elements of the helix, namely academia, government and industry. The support of the mass media and the public is very important to strengthen the concept of Penta Helix synergy to improve the creative economy.
\end{abstract}

Keywords: Penta helix, vocational, synergy

\section{Introduction}

This synergy relationship between the university as academia, industry and government is known as the triple helix. The triple helix concept was first introduced by Henry Etzkowitz and Loet Leydesdorff in analyzing the relationship between universities, industry and government. The Triple Helix innovation model focuses on the university-industry-government relationship. Today, the development of the helix consists of five related elements which are called the penta helix. The five elements are universities, government, industry, mass media and communities. The application of the Penta Helix model in university, especially vocational education, has not been studied much. The vocational field, especially those related to the creative economy, which is a priority for vocational education in Indonesia, needs to be studied more deeply. Therefore, this research will study the penta helix model in the Product Design Department of the Politeknik Negeri Samarinda as a vocational education in the creative economy field.

The Product Design Study Program is one of the study programs in the Samarinda State Polytechnic Design Department. Since its establishment for nearly 20 years, it has had dynamic 
organizational dynamics. Collaborative relationships with industry, government, media and communities have been established in recent times. The policy strategy used in recent years is a combination of both offensive and aggressive types. This is done considering that this study program is the only study program in the field of vocational product design that has a state status in the Eastern Indonesia region. The problem of this research is how is the implementation of the concept of the Penta helix innovation model in the vocational academic elements of case studies in the Product Design Study Program. The purpose of this study is to analyze the extent to which the Penta Helix innovation model is applied in the Product Design Study Program, especially in synergy with industry, government, mass media, and the community in the creative economy of product design.

\section{Literature Review}

The synergy relationship between university/academia, government and industry is a mutually beneficial relationship if executed properly. The concept of these three elements can build state strength because these elements support one another to gain the economic stability of a region. This concept is known as the triple helix [1][2]. The triple helix concept was first introduced by Henry Etzkowitz and Loet Leydesdorff in analyzing the relationship between universities, industry and government. This concept continues to be used by developing various supporting factors from the three elements. This model can describe the third slice, so that it can be explained in more detail the relationship between elements through the inter-element sections. This slice describes a synergistic and supportive relationship with one another [3][4]. The Triple helix pattern has been widely applied in the United States, European countries, India, Japan and China, and has brought rapid and continuous progress in building capacities in science and technology applied in industry and governance. Higher education institutions must improve themselves so that they are able to develop the capacity of science and technology, and can create development strategies guided by the university [5][6]. Several similar studies have linked the development and benefits of the triple helix model, which is a source of inspiration for policies and programs aimed at driving innovation [7][8].

In addition, the role of lecturers at universities is very much needed in the concept of halix as one of the main factors in the elements of the university. Lecturer research as a result of the university can be beneficial to industry as a knowledge transfer collaboration within the framework of the helix element synergy [9][10]. In line with that, the shift to managing innovation by establishing and assessing a business incubator can also support the synergy development of the triple helix [3]. The role of alumni as outputs from the university can indirectly improve work relations and customer satisfaction [11]. The development of the triple helix, it is very possible that there is an important role from the fourth party of the model, namely the association or community that is outside the three elements of the triple helix [4].

Currently, the development of the triple helix model has expanded to a wider area, namely the penta helix model which consists of five synergistic elements. This is due to the changing dynamics and needs in the current era of globalization. Penta Helix which consists of five elements of collaboration; namely the government, academia, environmental institutions and institutions have several weaknesses. This weakness was found in this study, namely the role of academics and environmental institutions [12]. Both are weak because that weakness can carry out the desired realization from tourism development in case studies to developing the tourism sector which is a synergistic tourism development model [13]. 


\section{Method}

This research method is to use the snowball technique, this technique is a multistage technique, based on the analogy of a snowball, which starts with a small snowball and then gradually enlarges due to the addition of snow when rolled in the snow [14]. In other words, this technique determines the initial informant correctly. This initial informant was the Head of the Product Design Study Program like seen in Figure 1. Furthermore, the information and data from this informant will roll over to other informants who are appointed until sufficient data is obtained.

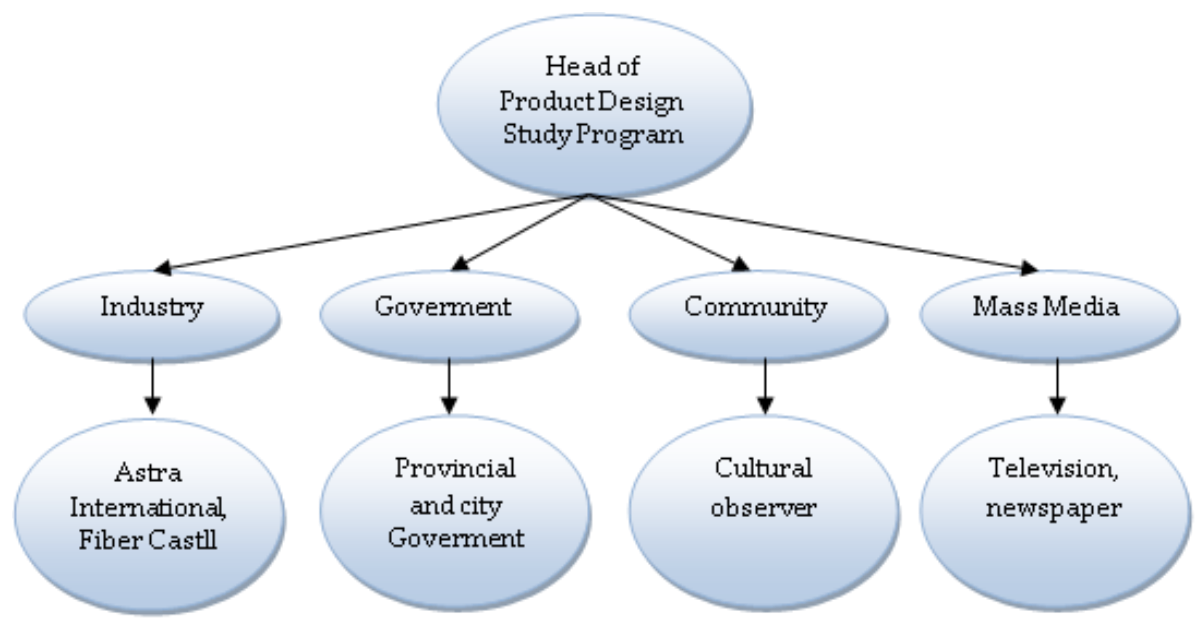

Fig.1. Snowball Technique

\section{Results and Discussion}

\subsection{Identification of Penta Helix Model}

This model is called the Quadruple Helix which is an extension of the triple helix by adding as a fourth helix media and community [15]. For the Quintuple Helix innovation model, the natural environment of society and the economy must also be seen as drivers for knowledge production and innovation, thereby defining opportunities for the knowledge economy [16]. Developing synergies with industry and government can be done through innovations from the university [17]. The development of the helix model is currently the penta helix model.

The university is an initiator in the synergy of these five elements. As an initiator in higher education, this is the foundation for developing a synergy model for university in the vocational field. Industry is the user of university graduates and the first partner in this penta helix model. Industry can act as partners in designing curricula so that they can take advantage of graduates according to their needs. The government is the regulator of every step taken by the University and industry in the field of education. Mass media in principle helps in promoting all activities carried out by academia, industry and government in the field of vocational education. With the mass media, information on all activities carried out will be more quickly accepted by the 
environment / community. This community plays a role in activities related to problems that occur in society and the environment in an activity.

\subsection{Implementation of vocational education on the Penta Helix Model} Model.

In Figure 2 we can see implementation of vocational education on the Penta Helix

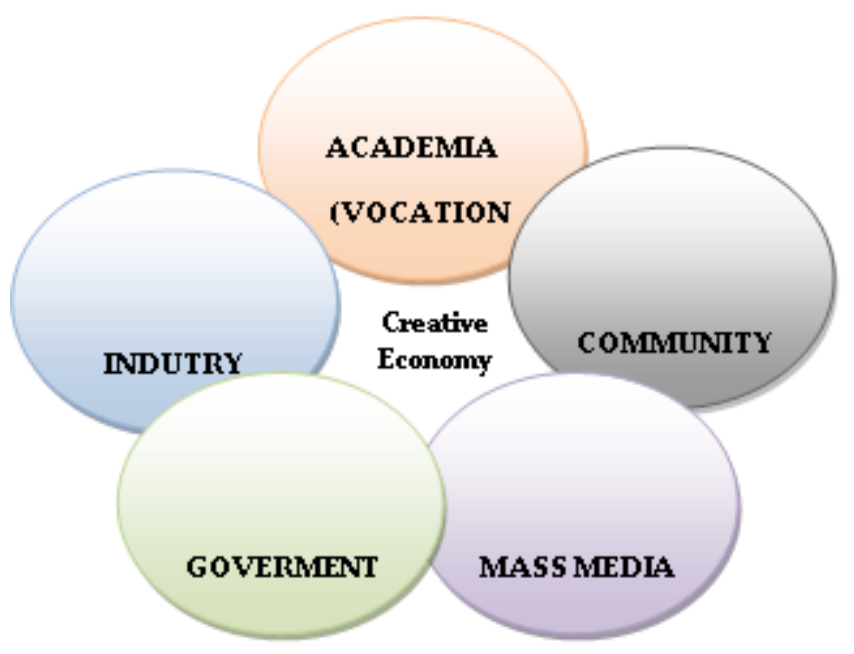

Fig. 2. Implementation of vocational education on the Penta Helix Model

The role of academics in this concept is as an initiator. Where the output of this element is products and services. The products and services produced are the result of innovation from research carried out on an ongoing basis to solve problems that exist around society. In addition, tertiary institutions contribute in the form of thoughts that solve problems conveyed by the research team. In addition, tertiary institutions also produce prospective workers in the form of students who have received both theoretical and practical education to be able to work in other elements to increase the creative economy.

The elements of higher education/university produced many innovations and products both thought and research results, that could help solve problems faced by the community in the form of options from problem-solving solutions that could be chosen according to their needs. For the Product Design Study Program, which is a vocational education, it has different characteristics from university. The real difference is in terms of lectures where vocational education is $80 \%$ of education is practice and $20 \%$ is theory. The Product Design Study Program focuses more on practical applications in the design of industrial products as a support for the creative economy industry, especially in the East Kalimantan region.

The role of industry in the Penta Helix concept is very important. Industry, government and academia/university were the foundations for the helix concept, known as the triple helix. Industry plays a role as a partner in developing the direction of the education curriculum in higher education, especially in the vocational field. In addition, the industry is also the recipient of the results of graduates and real training venues from staff and students. The role of industry and the Product Design Study Program is evident in the implementation of student field work 
practice places, industrial visits, and training platforms for staff to improve and harmonize what is taught on campus according to industry needs. Meanwhile, from the industrial side, they accept graduates from universities and receive ideas or solutions to problems faced by industry that can be solved on campus by researchers.

The government as a regulator on the Penta Helix element is tasked with producing regulations and monitoring the implementation of these regulations as an activity of a region or country. The perceived role of the government in the Product Design Study Program is related to the regulation of regulations on universities. Regulations regarding tertiary institutions such as the minimum education for lecturers are master education, nomenclature management, as well as several rules in campus activities that affect the space for this department. The government also provides facilities with physical and non-physical funding assistance. Physical in nature include facilities and pre-class facilities, while non-physical means are scholarship assistance for staff and students as well as assistance such as research grants and community service. The Product Design Study Program has just started interacting with this element several years ago and has started to get intense.

The next element is community. Community in this case is always related to environmental issues. The current environment is an important issue in the era of globalization related to global warming. The Product Design Study Program has played an active role in helping to overcome this problem. Several lecture activities have been carried out by utilizing these natural resources with the assistance of several environmental observer communities. One of the things that is most often done is the use of waste or unused materials to be used as handicraft products that have aesthetic value and sale value. Utilizing this waste by utilizing the surrounding environment is a shared responsibility in the synergy of the penta helix system.

\section{Conclusion}

The contribution of this research is to show that the Penta Helix innovation model can be applied in the world of education, especially in the field of vocational education in synergy with industry, government, mass media, and society in the creative economy of product design. The support of the mass media and the public is very important to strengthen the concept of Penta Helix synergy in vocational education to help and increase growth in the creative economy.

\section{Acknowledgement}

We would like to express our deepest gratitude to Samarinda State Polytechnic who funded this research. In addition, we would like to thank the 2nd Borobudur International Symposium on Humanities and Social Sciences organized by the University of Muhammadiyah Magelang for facilitating our scientific journals.

\section{References}

[1] Sitorus Hasan MS. "Peranan Perguruan Tinggi Dalam Penerapan Triple helix”. Harian Jurnal Asia. 2016. 
[2] Luis Farinha and João J. Ferreira. "Triangulation of The Triple Helix: A Conceptual Framwork." University of Beira Interior (UBI), Covilhã, Portugal. 2013

[3] Amaral Marcelo. "Management and assessment of innovation environments", Triple helix Journal. 2:19. 2015.

[4] Harley Balzer Harley, and Askonas Jon. "The Triple helix after communism: Russia and China compared." Triple helix Journal. 2016.

[5] Etzkowitz Henry. "University-Industry-Government: The Triple helix Model of Innovation." EOQ Congresses Proceedings. 51st EOQ Congress. 2017.

[6] Newman Melissa D. "Does membership matter? Examining the relationship between alumni association membership and alumni giving". International Journal of Educational Advancement. Vol. 10, 4, 163-179. 2011.

[7] Carlos Rodrigues and Ana I Melo. "The Triple Helix Model as Inspiration for Local Development Policies: An Experience-Based Perspective. International Journal of Urban and Regional Research. Volume 37. pp 1675-87. 2013.

[8] La Paz Ariel, Cancino Christian, Miranda Jaime. "Start-ups success using public funds: university versus industry sponsorship.” Multidisciplinary Business Review, Vol. 5, No. 1, pp. 38-45. 2012.

[9] Perkmanna Markus et al. "Academic engagement and commercialisation: A review of the literature on university-industry relations.” Elsevier B.V. Research Policy 42. 423-442. 2013.

[10] Pahurkar Rajesh N. "Creating Entrepreneurs through Entrepreneurial Universities". Scientific \& Academic Publishing. 5(2): 48-54. 2015.

[11] Ahmadi Hossein et al. "Customer Relationship Management Model for UTM Alumni Liaison Unit “. International Journal of Engineering and Innovative Technology (IJEIT). Volume 2, Issue 5, November. 2012.

[12] Novy Setia Yunas. "Implementasi Konsep Penta Helix dalam Pengembangan Potensi Desa melalui Model Lumbung Ekonomi Desa di Provinsi Jawa Timur.” Jurnal Inovasi Kebijakan. 2019.

[13] Willy Tri Hardiantoa, Sumartonob, M.R. Khairul Mulukc, and Fefta Wijayad, "PentaHelix Synergy on Tourism Development in Batu, East Java". International Journal of Innovation, Creativity and Change. Volume 10, Issue 6, 2019.

[14] Tri Yuniningsih, Titi Darmi and Susi Sulandari. "Model Pentahelik Dalam Pengembangan Pariwisata di Kota Semarang. Journal of Public Sector Innovation, Vol. 3, No. 2, Mei Tahun 2019.

[15] Elias G Carayannis, Thorsten D Barth and David F J Campbell. "The Quintuple Helix innovation model: global warming as a challenge and driver for innovation. Journal of Innovation and Entrepreneurship, 1:2. 2012.

[16] Aflit Nuryulia Praswati." Perkembangan Model Helix Dalam Peningkatan Inovasi." Seminar Nasional Riset Manajemen \& Bisnis. 2017.

[17] Alrence Santiago Halibas, Rowena Ocier Sibayan, and Rolou Lyn Rodriguez Maata. "The Penta Helix Model of Innovation in Oman: an HEI Perspective.” Interdisciplinary Journal of Information, Knowledge, and Management”. Vol. 12, 2017. 